\title{
OTONOMI PENDIDIKAN DAN KURIKULUM BERBASIS KOMPETENSI SEBAGAI JAWABAN ATAS REALITAS KEKINIAN
}

\author{
Naning Yuliani \\ STAI Al Azhar, Menganti Gresik_Jl. Raya Menganti Krajan No 447 Gresik \\ Naningyuliani@gmail.com
}

\begin{abstract}
The reform movement that wants a democratic social order in Indonesia has given birth to a national education system that is no longer centralistic. In a democratic education system, people are given the freedom to develop according to their abilities and potential. Recognition of the community to develop autonomously will spur the dynamics of society so that it becomes a developed society and science-powered. Thus, education autonomy will empower schools as the spearhead of the decentralization of education and encourage schools to improve quality in accordance with the potential of schools. Therefore, the government issued a school-based management policy and community-based education. along with the decentralized education system, it is necessary to apply a non-single curriculum that can be applied to all schools. A curriculum is needed that can be applied to schools according to the needs and abilities of the school. A single curriculum will encourage schools to increase creativity and high competitiveness so that superior and quality schools are born. In addition to the demands for decentralization, the national education system needs to be supported by a curriculum that can answer the current order, such as the demands of democratization, the challenges of the era of universalism, and the low quality of education in Indonesia. curriculum that can accommodate the demands of democratization will give birth to a new Indonesian society. namely civil society, fierce competition in the era of globalization requires a curriculum design that can lead the Indonesian people to achieve excellence in mastering science and technology. The low quality of education in Indonesia, one of which is due to curriculum patterns that are not able to equip students with life skills that shape creative, critical, independent and productive attitudes. Today's demands have given birth to a Competency Based Curriculum.
\end{abstract}

Keywords: Autonomy of education, school empowerment, Competency Based Curriculum.

\begin{abstract}
ABSTRAK
Gerakan reformasi yang menghendaki tatanan sosial demokratis di Indonesia, telah melahirkan sistem pendidikan nasional yang tidak lagi sentralistik. Dalam sistem pendidikan demokratis, masyarakat diberikan kebebasan untuk berkembang sesuai dengan kemampuan dan potensi yang mereka miliki. Pengakuan terhadap masyarakat untuk berkembang secara otonom akan memacu dinamika masyarakat sehingga menjadi masyarakat yang maju dan berdaya sains. Dengan demikian, otonomi pendidikan akan memberdayakan sekolah-sekolah sebagai ujung tombak desentralisasi pendidikan dan mendorong sekolah-sekolah meningkatkan kualitas sesuai dengan potensi sekolah. Oleh karena itu, pemerintah mengeluarkan kebijakan manajemen berbasis sekolah dan pendidikan berbasis masyarakat. seiring dengan sistem desentralisasi pendidikan, perlu diterapkan kurikulum yang tidak tunggal yang dapat diberlakukan untuk semua sekolah. Dibutuhkan kurikulum yang dapat diterapkan untuk sekolah-sekolah sesuai dengan kebutuhan dan kemampuan sekolah. Kurikulum yang tidak tunggal akan dapat mendorong sekolah meningkatkan kreativitas dan daya saing tinggi sehingga lahirlah sekolah-sekolah yang unggul dan berkualitas. Selain tuntutan desentralisasi, sistem pendidikan nasional perlu didukung kurikulum yang dapat menjawab tatanan kekinian, seperti tuntutan demokratisasi, tantangan era kesejagatan, dan rendahnya kualitas pendidikan di Indonesia. kurikulum yang dapat mewadahi tuntutan demokratisasi akan melahirkan masyarakat baru Indonesia. yaitu masyarakat madani persaingan ketat di era globalisasi menghendaki desain kurikulum yang dapat mengantarkan bangsa Indonesia mencapai keunggulan dalam penguasaan ilmu pengetahuan dan teknologi. Rendahnya kualitas pendidikan di Indonesia, salah satunya disebabkan pola kurikulum yang tidak mampu membekali peserta didik dengan kecakapan hidup yang membentuk sikap kreatif, kritis, mandiri dan produktif. Tuntutan kekinian telah melahirkan Kurikulum Berbasis Kompetensi.
\end{abstract}

Kata kunci: Otonomi pendidikan, pemberdayaan sekolah, Kurikulum Berbasis Kompetensi.

(C) (2020) Program Studi Pendidikan Guru Madrasah Ibtidaiyah

STAI Al-Azhar Menganti Gresik, Indonesia 


\section{Pendahuluan}

Lahirnya UU No.29/99 tentang otonomi daerah adalah sebuah langkah baru bagi lahirnya sistem pendidikan yang demokratis dan tidak lagi memusat. Sebab, dalam undang-undang tentang otonomi daerah ini wilayah (daerah) berhak mengelola sistem pendidikan sesuai kebutuhan lokal daerah. Undang-undang otonomi daerah meletakkan kewenangan sebagian besar pemerintahan bidang pendidikan dan kebudayaan yang selama ini berada pada pemerintahan pusat kepada pemerintahan daerah (Kabupaten/kota).

Lahirnya undang-undang No. 221999 merupakan konsekuensi dari keinginan reformasi untuk menegakkan kehidupan demokrasi. sistem pemerintahan sentralistik melahirkan sistem pendidikan nasional yang bersifat birokratik-sentralistik. Sistem pendidikan yang selama ini sepenuhnya dikelola secara birokratik dan sentralistik dianggap "biang keladi" yang telah memurukkan mutu dan keunggulan pendidikan. Ini terjadi, karena sistem birokrasi dalam menempatkan "kekuasaan". Sebagai faktor paling menentukan dalam proses pengambilan keputusan. Sekolah-sekolah saat ini telah terkungkung oleh kekuasaan birokrasi yang "menggurita" dari tingkat pusat hingga daerah. Kebijakan yang sentralistik cenderung melahirkan keseragaman, yang pada gilirannya mengabaikan keragaman sesuai dengan realitas kondisi, ekonomi dan budaya masyarakat Indonesia di daerah. Kebijakan pendidikan nasional hampir tidak memberikan ruang gerak yang memadai bagi masyarakat di wilayah atau daerah tertentu untuk mengembangkan pendidikan yang sesuai dan relevan dengan daerah dan kebutuhanb masyarakatnya sendiri.

Desentralisasi pendidikan diperlukan untuk mewujudkan masyarakat baru yang demokratis. Kehidupan demokratis tidak akan terwujud apabila segala sesuatu ditentukan oleh pusat. Ciri-ciri kehidupan demokratis adalah diakuinya kebebasan berbicara dan berpikir kritis. Hak-hak asasi manusia diakui dan dikembangkan dalam batas-batas kemerdekaan. Demokrasi akan mati apabila kebebasan berpendapat, berpikir, dan bertindak dibatasi. Akibatnya, lahirlah manusia-manusia yang tidak kreatif. Perkembangan masyarakat menjadi lamban dan tidak produktif

\section{MAKNA OTONOMI}

Desentralisasi pendidikan adalah pengalihan tanggung jawab atas perencanaan, manajemen, penggalian dan alokasi sumber daya dalam pendidikan dari pemerintah pusat dan perwakilannya kepada unit-unit pelaksana pendidikan, unit-unit di bawah pemerintah pusat, otoritas public dan korporasi-korporasi semi otonom, otoritas regional atau fungsional yang lebih luas, atau lembaga swadaya masyarakat. Dalam desentralisasi ada pelimpahan wewenang, baik secara luas atau sempit. Desentralisasi yang dikehendaki adalah dekonsentrasi wewenang dari pusat kepada unit di bawah sesuai dengan garis kebijakan pusat. Dengan demikian, otonomi pendidikan adalah dekonsentrasi wewenang dari pemerintah pusat kepada pemerintah daerah, masyarakat, bahkan kepada sekolah 
sebagai ujung tombak otonomi pendidikan. Penyelenggara pendidikan tidak lagi menjadi tanggung jawab pemerintah pusat, tetapi juga melibatkan pemerintah daerah, masyarakat dan sekolah.

Makna sebenarnya dari otonomi pendidikan adalah mengembalikan tanggung jawab pendidikan kepada the stakeholder, yaitu masyarakat itu sendiri. dalam otonomi pendidikan, masyarakat secara langsung bertanggung jawab atas keberadaan dan proses pendidikan yang dimiliki (Satjipto Raharjo, 2010). Penyelenggara pendidikan harus mengikutsertakan masyarakat karena masyarakat adalah the stakeholder yang pertama dan utama dari proses pendidikan. Dengan demikian, proses pendidikan, tujuan pendidikan dan sarana pendidikan, termasuk pula mutu pendidikan merupakan tanggung jawab masyarakat setempat. Partisipasi masyarakat yang tinggi cenderung mendorong sekolah menjadi maju. berdasarkan penelitian, sekolah yang termasuk kategori unggul, mengoptimalkan keterlibatan masyarakat, terutama orang tua dalam mencapai tujuan sekolah. Orang tua murid diberi kesempatan seluas-luasnya untuk mengenali sekolah, bukan saja bentuk fisiknya tetapi juga program pendidikannya (Moedjiarto, 2002).

Di Indonesia partisipasi masyarakat terhadap pendidikan sangat lemah meskipun sebagian besar lembaga-lembaga pendidikan didanai oleh masyarakat. partisipasi masyarakat terhadap proses pendidikan belum optimal. Hal ini disebabkan sistem pendidikan yang sentralistik sehingga organisasi penyelenggara pendidikan telah mengabaikan tanggung jawab masyarakat. dalam sistem pendidikan sentralistik tanggung jawab masyarakat. dalam sistem pendidikan sentralistik, organisasi penyelenggara pendidikan telah mengasingkan diri dari masyarakat dan jauh dari usaha pemberdayaan masyarakat.

Oleh karena itu perlu dikembangkan pendidikan berbasis masyarakat (community based education). Adapun tujuan pengembangan platform pendidikan berbasis masyarakat adalah: pertama, membantu pemerintah dalam memobilisasi SDM setempat dan dari luar serta meningkatkan peranan masyarakat untuk ambil bagian lebih besar dalam perencanaan, pelaksanaan, evaluasi pendidikan di semua jenjang, jenis dan jalur pendidikan. Kedua, mendorong perubahan sikap dan persepsi masyarakat terhadap rasa kepemilikan sekolah, tanggung jawab. Ketiga, mendukung inisiatif pemerintah dalam meningkatkan partisipasi masyarakat terhadap sekolah melalui kebijakan desentralisasi. Keempat, mendukung peranan masyarakat dalam mengembangkan inovasi kelembagaan untuk melengkapi, meningkatkan, dan mengganti peran sekolah, dan untuk meningkatkan mutu dan relevansi; membuka kesempatan lebih besar dalam memperoleh pendidikan; serta meningkatkan efisiensi manajemen pendidikan dasar untuk wajib belajar pendidikan dasar, menengah dan tinggi.

Otonomi pendidikan nasional diwujudkan dengan MBS (manajemen berbasis sekolah). Dalam MBS sekolah diberi wewenang untuk merancang keuangan, pengembangan kurikulum, termasuk tujuan dan sasaran pendidikan, alokasi waktu, serta pemanfaatan media, sumber, instrumen dan teknologi bagi pendidikan untuk mencapai efisiensi dan efektifitas yang optimal. Konsep 
manajemen berbasis sekolah adalah pengelolaan sekolah dengan pelimpahan wewenang tertentu, tetapi tetap dalam kerangka kebijakan nasional.

Konsep desentralisasi dalam sistem pendidikan nasional lebih mengacu pada sekolah manajemen mandiri (self-managing schools) daripada penyelenggara mandiri (self-governing schools). Desentralisasi pendidikan bukan berarti penciutan substansi pendidikan yang bersifat sempit dan lokal yang dapat melahirkan sentimen kedaerahan, tetapi pelimpahan kekuasaan dan wewenang kepada daerah dan sekolah dalam mengelola berbagai sumber meliputi ketenagaan, keuangan, kurikulum serta sarana dan prasarana yang mengacu kebijakan nasional.

Dalam merealisasi desentralisasi pendidikan, konsep manajemen berbasis sekolah tidak dapat dipisahkan dari konsep pendidikan berbasis masyarakat. di era otonomi, partisipasi masyarakat sebagai kekuatan kontrol dalam penyelenggaraan pendidikan sangat penting. Partisipasi masyarakat diharapkan menjadi kekuatan kontrol bagi pelaksanaan dan peningkatan kualitas sekolah. Oleh karena itu, lahirlah gagasan komite sekolah yang berperan sebagai mitra sekolah yang menyalurkan partisipasi masyarakat. komite sekolah berfungsi menjaga transparansi, akuntabilitas sekolah dan menyalurkan partisipasi masyarakat pada sekolah.

Dalam konteks desentralisasi MBS dan komite sekolah saling berkaitan. Jika MBS dan komite sekolah berjalan, proses demokratisasi pendidikan telah berjalan dan tanggung jawab pendidikan telah dikembalikan kepada masyarakat karena masyarakat tentunya yang memiliki sustainability (kemampuan menopang)a yang handal untuk mencapai pendidikan yang berkualitas. Namun demikian, pengembangan manajemen berbasis sekolah masih sangat sulit karena sudah puluhan tahun manajemen pendidikan nasional bersifat sentralistik sehingga perlu waktu dan keberanian untuk berubah. Partisipasi masyarakat sangat membantu implementasi manajemen berbasis sekolah. Namun, dibutuhkan waktu dan tenaga untuk menggalang peran serta masyarakat dalam proses pendidikan mengingat selam ini sistem pendidikan nasional terisolasi dari peran serta masyarakat.

\section{PEMBERDAYAAN SEKOLAH}

Tujuan dari otonomi pendidikan adalah pemberdayaan lembaga-lembaga pendidikan sehingga menjadi lembaga yang mandiri. Dengan demikian, otonomi pendidikan harus membebaskan lembagalembaga pendidikan dari kungkungan birokrasi dan menjadi lembaga profesioanl dengan tanggung jawab jawab jelas (Tilaar, 2002).

Selama ini lembaga pendidikan terjebak dalam sistem birokratis sentralistik. Kebijakankebijakan dan program-program pendidikan ditentukan oleh pusat, akibatnya lahirlah kebijakan uniformitas sehingga pendidikan tercabut dari tanggung jawab masyarakat. sekolah-sekolah tidak mampu mengembangkan kreativitas dan kemandirian. Oleh sebab itu, lembaga pendidikan kehilangan relevansi dengan kehidupan nyata dan tidak mampu melahirkan output yang kritis dan inovatif. 
Otonomisasi akan memberikan wewenang kepada unit pelaksana terdepan untuk mengambil keputusan sendiri sesuai dengan tuntutan, tidak menunggu keputusan dari pusat. Hal ini akan mendorong unit-unit pelaksana bersifat kreatif dan mandiri. Pada gilirannya, akan tumbuh kemampuan daya saing yang tinggi. Sikap saling menyingkirkan, tetapi dalam kerangka kerjasama untuk saling meningkatkan kualitas. iklim kompetitif akan mendorong rasa tidak puas dengan apa yang telah dicapai sehingga membuka peluang untuk saling melahirkan ide-ide baru. Kemampuan inovasi yang akan membawa sekolah-sekolah menjadi sekolah yang unggul dan mampu bersaing. Hanya sekolah yang unggul dan mampu bersaing di era persaingan global. Sedangkan sekolah yang lemah akan tertinggal dan tidak mampu eksis di tengah kehidupan global dan terbuka.

Ada beberapa hal yang perlu diperhatikan dalam mewujudkan sekolah-sekolah unggul. pertama, dalam rangka melaksanakan tugas-tugas dekonsentasi di sekolah diperlukan kepala sekolah yang cakap dan dapat membuat perencanaan buletin, dan memahami secara mendalam visi dan misi pendidikan nasional untuk mengimplementasikan dalam program-program sekolah. Program-program pendidikan di sekolah dapat diselaraskan dengan arah dan kebijakan pendidikan nasional, maka dibutuhkan kepemimpinan kepala sekolah yang dapat memberdayakan, mengoptimalkan, dan mengarahkan segala sumber daya untuk peningkatan kualitas pendidikan.

Kedua, dibutuhkan manajemen sekolah yang bagus bukan rahasia lagi. Banyak sekolah yang menerapkan manajemen "asal jalan”. Kegiatan pendidikan tidak direncanakan dengan baik. terkadang sekolah dikelola oleh keluarga-keluarga dengan kepemimpinan yang otoriter. Arus informasi tidak berjalan dengan baik. di sekolah tidak memiliki saluran untuk menyampaikan pendapat dan kritik, yang biasanya disebabkan budaya "ewuh pakewuh" (keengganan menyampaikan pendapat dan kritik karena segan pada pemimpinan). Kondisi ini mempersulit sekolah untuk berkembang dengan baik. sulit bagi sekolah dengan manajemen demikian untuk melakukan perubahan karena terbentur sikap otoriter pemimpin yang disegani. Terkadang program-program reformasi terhambat karena sikap pemimpin yang takut kehilangan pengaruh dan jabatan.

Ketiga, diperlukan SDM yang berkualitas. Secara umum kualitas sumber daya manusia di Indonesia sangat rendah. Mereka pada umumnya belum memenuhi standar sebagai guru bidang studi. Tidak jarang wawasan keilmuannya masih sempit. Sekolah-sekolah miskin, merekrut tenaga pendidikan seadanya. Jumlahnya pun kurang memadai karena mereka tidak memiliki dana cukup untuk menggaji guru. Sehingga seorang guru harus memegang beberapa mata pelajaran. Kekurangan SDM yang berkualitas akan mempersulit sekolah untuk melakukan reformasi pendidikan. Peningkatan kualitas pendidikan membutuhkan tenaga pendidikan yang berkualitas dan profesional.

Keempat, harus didukung dana dan fasilitas yang memadai secara umum. Sekolah di Indonesia tidak memiliki sarana pendidikan yang layak sebagai sebuah lembaga pendidikan. Bahkan, beberapa waktu lalu, dunia pendidikan harus dikejutkan robohnya gedung sekolah di beberapa daerah. Lokasi sekolah miskin sering ditemukan di pinggiran kita, di lingkungan yang kumuh, di gang-gang 
sempit, dan di tengah lingkungan masyarakat ekonomi lemah. Ini menyebabkan pendanaan dan penyediaan fasilitas pendidikan yang seadanya saja. Padahal, untuk menghasilkan sebuah sistem pendidikan dan output (siswa) yang berkualitas, sarana pendidikan sangat menentukan, di samping faktor kualitas tenaga pendidikan. Bagi sekolah miskin, menyediakan gedung yang representatif, ruang UKS, sarana komputer, serta laboratorium (IPA dan Bahasa) merupakan suatu hal yang mustahil bila tidak mendapatkan bantuan pemerintah, selain orang yang memiliki kepedulian terhadap pendidikan. Sekolah miskin biasanya hanya bergantung pada dana dari siswa yang jumlahnya sangat kecil. Padahal sekolah bermutu itu mahal.

Pemberdayaan sekolah (school empowerement) untuk menyediakan sistem pendidikan bermutu kepada masyarakat harus ditunjang empat aspek tersebut di atas, yaitu kepemimpinan instruksional, manajemen yang rapi, tenaga pendidikan profesional, serta dana dan fasilitas pendidikan yang memadai. Sekolah yang dikelola dengan tertib dan rapi akan memiliki kesempatan besar untuk menjadi sebuah lembaga pendidikan yang berkualitas. Jika empat aspek tersebut dimiliki oleh sekolah-sekolah swasta, sekolah-sekolah swasta akan dapat mengalahkan mutu sekolah-sekolah pemerintah.

Apabila sekolah memiliki empat aspek yang dibutuhkan dalam pemberdayaan sekolah, tidak tertutup kemungkinan sekolah tersebut akan menjadi sekolah efektif, yang kreatif, inovatif, dan mandiri. Jika demikian, pemberdayaan sekolah akan melahirkan sekolah-sekolah yang otonom. Sekolah-sekolah otonom inilah yang menjadi ujung tombak reformasi pendidikan dalam kerangka desentralisasi pendidikan.

Otonomi pendidikan adalah suatu keniscayaan (necessary) karena otonomi akan menjadi daya dorong bagi sekolah-sekolah untuk meningkatkan kreativitas. Dalam otonomi pendidikan, yang mengimplikasikan persaingan, semua sekolah dituntut mampu bersikap mandiri, kreatif dan inovatif agar dapat menyediakan sistem pendidikan berkualitas. Persaingan bukan berarti negatif karena persaingan mampu mendorong kepada kemajuan.

Namun demikian, otonomi pendidikan bukan berarti serta merta dapat meningkatkan kualitas pendidikan di Indonesia. pertama, desentralisasi yang memberikan kewenangan-kewenangan tertentu kepada otoritas daerah, akan memindahkan "borok-borok" pusat ke daerah. Penyelewengan kekuasaan oleh kelompok elit pusat akan berkembang di kalangan penguasa elit daerah. Praktekpraktek korupsi, kolusi, dan nepotisme di daerah. Desentralisasi tanpa kontrol kuat oleh masyarakat tidak akan membawa perubahan dalam pendidikan di Indonesia karena pendidikan tetap dapat diselenggarakan oleh segelintir orang untuk kepentingan mereka sehingga pendidikan akan tetap dikebiri oleh penguasa sebagaimana yang selama ini terjadi.

Kedua, otonomi pendidikan akan memperlebar kesenjangan antara sekolah maju dan sekolah terbelakang. Masalah yang muncul dalam otonomi pendidikan adalah kesiapan sekolah-sekolah sebagai ujung tombak dari implementasi otonomi pendidikan. Dalam sistem pendidikan di Indonesia, 
ada dua jenis sekolah yang berbeda, yakni negeri dan swasta. Sekolah negeri adalah lembaga pendidikan yang didirikan dan dibiayai pemerintah. Sedangkan sekolah swasta adalah lembaga pendidikan yang didirikan dan dibiayai oleh swasta (masyarakat). sekolahan negeri dengan segala kelebihan yang dimiliki tidak sebanding dengan sekolah swasta. Dari segi wujud fisik dan serana penunjang pendidikan, sekolah negeri jauh lebih memadai. Begitu pula dengan manajemen dan mutu pendidikannya. Sebab, kebutuhan pendidikan sekolah negeri dapat terpenuhi. Sedangkan sekolah swasta sebagian besar kondisinya memprihatinkan yang tergolong sekolah miskin.

Otonomi pendidikan merupakan tantangan berat bagi sekolah-sekolah untuk dapat bersaing dengan sekolah-sekolah maju. mekanisme pasar telah mewarnai pendidikan Indonesia. fenomena mekanisme pasar dalam pendidikan dapat dilihat dari sikap orang tua calon siswa yang menjadikan sekolah-sekolah swasta unggulan dan sekolah-sekolah negeri teladan sebagai pilihan utama mereka. sedangkan sekolah-sekolah yang terbelakang ditinggalkan oleh masyarakat. mereka memilih sekolahsekolah favorit dan teladan karena sekolah teladan dilengkapi dengan fasilitas yang memadai. Kedisiplinan di sekolah teladan cukup tinggi sehingga pembelajaran berjalan efektif. Itu sebabnya rangking nilai siswa favorit sangat tinggi. Siswa dari sekolah favorit memiliki peluang besar melanjutkan ke Perguruan Tinggi Negeri (PTN) atau Perguruan Tinggi Luar Negeri (PTLN) dibandingkan dengan siswa yang berasal dari sekolah non favorit. Selain itu, orang tua memasukkan putra-putrinya ke sekolah favorit bertujuan menyiapkan masa depan anaknya yang lebih baik agar mampu menghadapi tantangan dan persaingan hidup.

Sekolah-sekolah miskin yang sebagian besar adalah sekolah Islam termasuk madrasah yang kekurangan siswa akan terancam gulung tikar. Sedangkan sekolah-sekolah yang mempunyai kualitas tinggi akan terus eksis sehingga memacu sekolah lain untuk mengembangkan diri guna menjadikan pendidikan di Indonesia bisa bersaing di tingkat global. Apalagi, era globalisasi yang sudah merasuk ke bidang pendidikan, di mana asing diperbolehkan mendirikan lembaga pendidikan di Indonesia, sehingga persaingan sekolah-sekolah miskin tidak hanya di tingkat lokal atau nasional, tetapi juga internasional. Hanya sekolah-sekolah yang berkualitas tinggi yang dapat menjawab tantangan globalisasi.

\section{DESENTRALISASI DAN KURIKULUM BERBASIS KOMPETENSI}

Desentralisasi sebagai konsekuensi reformasi total di Indonesia, tidak terlepas dari gerakan global, yaitu demokratisasi. Kehidupan demokrasi tidak akan berkembang dalam sistem sentralistik. Di mana segala sesuatu diatur dan ditentukan oleh pusat, akibatnya, kebebasan berfikir terpasung. Uniformitas berpikir dan bertindak melahirkan manusia-manusia robot yang tidak memiliki daya kreasi dan daya cipta. Maka, demokrasi menjadi terkubur dalam kemauan dan sikap otoriter penguasa.

Kehidupan demokrasi menjunjung tinggi penghargaan kepada potensi individu dan masyarakat. penghargaan terhadap potensi individu dan masyarakat akan menumbuhkan sikap dan kepribadian yang mandiri. Kehidupan demokrasi menentang penyalahgunaan kekuasaan. Dalam 
pendidikan, demokratisasi berarti tidak mentolerir pendidikan untuk tujuan dan kepentingan politik. Demikian pula, sikap indoktrinasi harus ditolak dalam pendidikan. Demokrasi dalam pendidikan berarti semua warga negara mempunyai hak yang sama untuk memperoleh pendidikan yang baik, juga mempunyai hak yang sama untuk membangun pendidikan nasional yang berkualitas.

Demokrasi bukan hanya masalah prosedur, tetapi juga merupakan nilai-nilai, yaitu nilai yang mengakui kehormatan atau martabat manusia. pendidikan harus mengembangkan nilai-nilai demokratis yang dirumuskan dalam tujuan pendidikan nasional. Pendidikan nasional bertujuan melahirkan pribadi-pribadi yang bertakwa, kreatif, kritis, dan produktif. Tujuan inilah yang akan dijabarkan dalam kegiatan pendidikan. Maka, kemudian diperlukan kurikulum yang akan dijadikan sebagai pedoman isi pendidikan

Tuntutan demokratisasi, tantangan era kesejagatan, dan rendahnya kualitas pendidikan membuat para ahli pendidikan berpikir keras untuk merumuskan kurikulum pendidikan nasional. Kurikulum baru diharapkan dapat mewadahi tuntutan demokratisasi untuk melahirkan masyarakat baru Indonesia, yaitu masyarakat madani yang berkualitas, berdaulat, terbuka, menghargai hak asasi manusia, menjunjung keseimbangan tatanan sosial dari individu.

Persaingan ketat di era globalisasi mendorong para ahli menemukan desain kurikulum yang dapat mengantarkan masyarakat Indonesia mencapai keunggulan dalam penguasaan ilmu pengetahuan dan teknologi. Pendidikan harus memiliki relevansi dengan kondisi dan tuntutan zaman. Kehidupan manusia dalam millennium ketiga, mempunyai dimensi bukan hanya dimensi domestik, tetapi global, kita hidup dalam dunia terbuka dan dunia tanpa batas borderless, yang di samping menjadi tantangan, juga membuka peluang baru dalam meningkatkan taraf hidup masyarakat. oleh karena itu, sistem pendidikan nasional memiliki tugas dan tanggung jawab untuk memberikan jawaban yang tepat terhadap tantangan dan peluang kehidupan global.

Rendahnya kualitas pendidikan di Indonesia, salah satunya disebabkan pada kurikulum yang tidak sesuai dengan lingkungan kehidupan dan kebutuhan peserta didik, kurikulum lama yang cenderung mengutamakan aspek kognitif, tidak mampu membekali peserta didik dengan kecakapan hidup yang membentuk sikap kreatif, kritis, mandiri, dan produktif. Akibatnya, bangsa Indonesia mengalami keterpurukan baik ekonomi, politik dan sosial budayanya. Bangsa Indonesia dihadapkan pada fenomena kekerasan, pelanggaran hak asasi manusia, penyalahgunaan narkoba, perkelahian antar pelajar. Bahkan sistem kurikulum lama melahirkan generasi yang tidak produktif sehingga bangsa Indonesia sealu kalah dalam persaingan global.

Dengan model kurikulum baru tidak serta merta seluruh permasalahan pendidikan dapat dipecahkan. Namun demikian, model kurikulum yang bagus akan dapat memberi makna yang signifikan bagi perbaikan mutu pendidikan. Sesuai dengan semangat desentralisasi, dibutuhkan kurikulum yang memberikan peluang dan kebebasan kepada sekolah untuk melakukan inovasi dan improvisasi yang tumbuh dari aktivitas, kreativitas dan profesionalisme yang dimiliki. Sekolah dapat 
mengajukan materi dan proses pembelajaran yang relevan dengan kebutuhan masyarakat, dan melakukan perbaikan yang berkesinambungan.

Seiring dengan sistem desentralisasi pendidikan, perlu diterapkan kurikulum yang tidak tunggal yang dapat diberlakukan untuk semua sekolah. Dibutuhkan kurikulum yang dapat diterapkan untuk sekolah-sekolah sesuai dengan kebutuhan dan kemampuan sekolah. Kurikulum yang tidak tunggal akan dapat mendorong sekolah meningkatkan kreatifitas dan daya saing tinggi sehingga lahirlah sekolah-sekolah yang unggul dan berkualitas. Oleh karena itu, pengembangan kurikulum tidak lagi menjadi otoritas pemerintah pusat, tetapi merupakan sharet activity dengan pemerintah daerah, bahkan masyarakat. pemerintah cukup menangani kurikulum pendidikan yang sifatnya inti. Sedangkan kurikulum yang sifatnya extended disusun dan dikembangkan oleh daerah sesuai dengan kebutuhan (Mulyasaa, 2002).

Berkaitan dengan perubahan kurikulum, berbagai pihak menganalisa perlunya diterapkan Kurikulum Berbasis Kompetensi yang dapat membekali peserta didik dengan berbagai kemampuan yang sesuai dengan tuntutan demokratisasi, tantangan global, dan dapat meningkatkan kualitas pendidikan. Kurikulum Berbasis Kompetensi akan mampu melahirkan generasi yang dapat memberikan konstribusi bagi pembangunan masyarakat dan kesejahteraan sosial. Kurikulum Berbasis Kompetensi diharapkan mampu memecahkan berbagai persoalan bangsa, khususnya dalam bidang pendidikan (Sholehuddin, 2007).

\section{Simpulan}

Tuntutan demokratisasai, tantangan global, dan rendahnya kualitas pendidikan di Indonesia, telah menyebabkan pergeseran sistem pendidikan nasional dan sistem pendidikan yang biroraktis sentralistik menjadi sistem pendidikan desentralistik. Penyelenggaraan pendidikan nasional yang birokratis-sentralistik telah menempatkan sekolah sebagai penyelenggara pendidikan yang sangat bergantung kepada keputusan birokrasi yang sangat panjang dan terkadang kebijakan yang diputuskan pemerintah pusat tidak sesuai dengan kondisi sekolah setempat. Akibatnya, berkembangnya budaya menunggu petunjuk dari pemerintah pusat sehingga sekolah tidak memiliki inisiatif dan kreatif. Sekolah menjadi kehilangan kemandirian. Pergeseran sistem pendidikan nasional dari sentralistik menjadi desentralistik, bertujuan memberdayakan sekolah sebagai ujung tombak otonomi pendidikan. Otonomi pendidikan memberikan kewenangan kepada sekolah untuk berpartisipasi dalam pengambilan keputusan untuk meningkatkan kualitas pendidikan dengan mengelola dan memberdayakan sumber daya yang tersedia. Sekolah yang lebih tahu kekuatan, kelemahan, sumber daya yang tersedia, dan kebutuhan sekolah sehingga dapat mengoptimalkan sumber daya untuk meningkatkan mutu pendidikan. Otonomi pendidikan berarti mengembalikan tanggung jawab pendidikan kepada masyarakat. Oleh karena itu, otonomi pendidikan membutuhkan dukungan dan partisipasi masyarakat dalam penyelenggaraan pendidikan karena masyarakat tentunya yang memiliki 
substainabiliti (kemampuan menopang) yang handal untuk mencapai pendidikan yang berkualitas. Seiring dengan sistem desentralisasi pendidikan, perlu diterapkan kurikulum yang tidak tunggal yang dapat diberlakukan untuk semua sekolah. Kurikulum ini akan memberikan peluang dan kewenangan kepada sekolah untuk lebih otonom dalam mengembangkan dan mengoperasionalkan pembelajaran di sekolah masing-masing. Dengan demikian, diversikasi dalam kurikulum akan memungkinkan sekolah untuk mengelola pelaksanaan pembelajaran sesuai kebutuhan dan kemampuan sekolah. 


\section{Daftar Pustaka}

Husein, M. W., \& Hufron. (2008). Hukum, Politik dan Kepentingan. Yogyakarta: Laks Bang PRESS indo.

Ibrahim, J. (2009). Pendekatan ekonomi terhadap hukum, teori dan implikasi penerapannya dalam penegakan hukum. Surabaya: ITS Press.

Mahfud, Moh. M. D. (2010). Membangun politik hukum, menegakkan konstitusi. Jakarta: Rajawali Pers.

Mulyasaa, E. (2002). Kurikulum Berbasis Kompetensi. Bandung: PT. Remaja Rosdakarya.

Raharjo, S. (2010). Penegakan hukum progresif. Jakarta: Kompas.

Sholehuddin. (2007). Modul Criminal Justice System. Surabaya.

(UUD No. 23 Tahun 2002)

Tilaar, HAR. (2002). Membenahi Pendidikan Nasional. Jakarta: Rineka Cipta. 